\title{
UNDERSEAT PRESSURE DISTRIBUTION IN THE SITTING SPINAL INJURY PATIENT
}

By R. J. Minns, B.Eng., M.Sc., Ph.D. ${ }^{1}$ R. A. Sutton, M.B., B.S., F.R.C.S. (Ed). ${ }^{2}$ A. Duffus, M.C.S.P. ${ }^{2}$ and R. MatTinson, S.R.N. ${ }^{2}$

${ }^{1}$ Regional Medical Physics Department, Durham Unit, Dryburn Hospital, Durham DHI $5 T W .{ }^{2}$ North of England Regional Spinal Injuries Unit, Hexham General Hospital, Hexham, Northumberland, U.K.

Summary. A device has been developed that can display underseat pressure distributions during sitting. We have found this device to be particularly useful in monitoring the effect of pressure sore surgery on the underseat pressure patterns, in the design of pressure-relieving cushions, and as a device to enable spinal injury staff to locate areas of high pressure at which tissue breakdown (pressure sores) may occur.

Key words: Pressure measurements; Pressure sores; Ischial pressures; Wheelchair cushions.

\section{Introduction}

IT is well known that spinal injury patients are very liable to develop ischaemic sores over the ischial tuberosities because of the high pressures and the duration of these pressures in these areas in the absence of sensation (Kosiak, 1959). There is great difficulty in measuring interface pressures between the skin and any supportive surface because of the perturbing effect of the sensors upon conditions at the interface (Ferguson-Pell, I980) and also, small pressure-sensing devices can only detect the average pressure over a small area. To build up a picture of the pressure patterns at a large interface multiple devices (Lindan et al., 1965), or multiple readings need to be taken and the data processed to produce pressure contours (Drummond et al., 1982). A pedobarograph (Chodera and Lord, 1978) can produce such profiles underneath a contacting surface bearing in mind that the detecting surface is flat and rigid and the values of pressures are likely to be extremely high. The pressure patterns can be related to anatomical variables and can be used for comparative studies between groups of subjects examined and can monitor the effects of anatomical modifications carried out surgically to patients, for example trimming of ischial tuberosities (Minns and Sutton, I982).

We report in this paper the design and clinical applications of an 'Ischiobarograph'. This apparatus displays seating pressure patterns and detects the precise location of, and the value of, high pressure under the ischial tuberosities.

We would stress that the measurements involved do not take place at the skin/cushion interface. The technique also requires that the trunkposture and leg positions employed during examination be defined or 
standardised since changes in either of these factors are known to modify ischial tuberosity pressure patterns (Bush, I969).

\section{Methods}

The pressure sensing device, or 'Ischiobarograph', is designed like a wheelchair with comparable dimensions. The height of the detecting surface on which the subjects or patients are seated is $50 \mathrm{~cm}$ from floor level, is $50 \mathrm{~cm}$ wide and has a backrest $20 \mathrm{~cm}$ high adjustable for both seat depth and rake angle. Two adjustable footrests are located at the front and are removable and pivot horizontally outwards during patient transfer (Fig. I). The frame

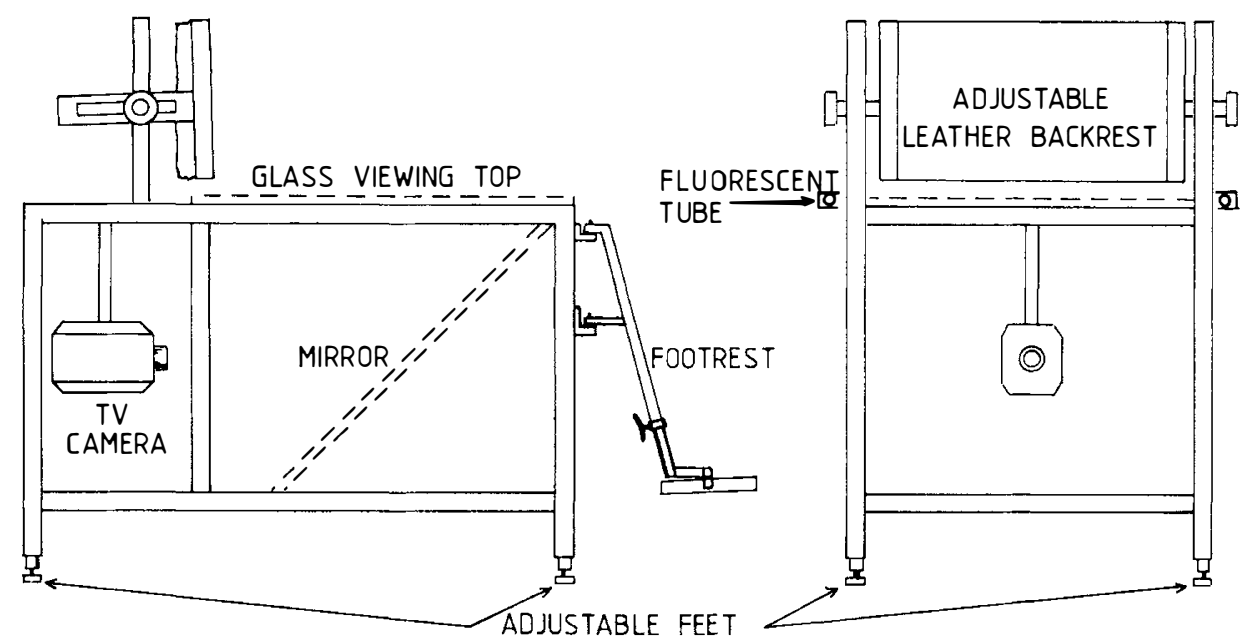

FIG. I

Diagram of the device showing the adjustable footrests and adjustable back support.

of the Ischiobarograph consists of $2.5 \mathrm{~cm}$ square tubed sections. Adjustable feet are located at the base of the four corner tubes for levelling. The detecting surface comprises a sheet of $50 \mathrm{~cm}$ square white spectacle crown glass $12 \mathrm{~mm}$ thick, with the surfaces and two opposite edges ground and optically polished. Two I 5 watt fluorescent tubes $52.5 \mathrm{~cm}$ long are located adjacent to the optically polished edges with a blackened surround to prevent stray lighting. The detecting foil on the glass is a I $00 \mu \mathrm{m}$ thick white polyvinylchloride (PVC) sheet with serrated indentations similar to the material used by Chodera and Lord (1978). This foil is covered by a black PVC sheet to eliminate light entering the glass from above the surface. Creep tests, conducted on samples of the white and black PVC material, show that for representative pressures commonly seen under the ischium of $200 \mathrm{KPa}$ the materials settle to equilibrium conditions within 2 minutes of application of load. An angled mirror within the frame deflects the optical path of what appears on the detecting surface to a horizontally mounted video camera. The video camera is a National Panasonic WV-I350 
CCTV camera containing a Newvicon S4075 tube which has more than twice the sensitivity of a silicon vidicon tube with excellent low light level characteristics down to 0.5 lux and a reproducible light detected-output voltage characteristics ideally suited to the Pedobarograph concept of light-level related to pressure exerted on the foil. The output from the camera passes through a colour analyser circuit which contains seven voltage comparators that generate seven colours at different grey scale light levels through the red/blue/green inputs of a colour monitor (Betts, I979). A Polaroid CU 5 camera with a hand-held optical hood was used for permanent copies of the pressure patterns detected by the Ischiobarograph on the colour monitor.

The normal subjects were asked to sit on the device with the backrest in its furthest position; the backrest was then brought forward until the subject was sufficiently supported at the back so that no muscular effort was required to maintain the trunk position. The legs were positioned such that the back of the calves were approximately $3 \mathrm{~cm}$ forward of the device front edge and the foot rests were positioned so that the thighs behind the knee were just free of the detecting surface. Footrest height, angles and backrest depth and angles were noted for each subject.

The spinal cord injury patients were placed centrally on the device and the posture adjusted so that it was the same as the position assumed in the wheelchair (i.e. the footrests were positioned such that the posterior distal thighs were just clear of the detecting surface and the backrest depth and angles were as for the wheelchair backrest position).

Documentation included a photograph of the buttock area of all the spinal cord injured patients under set flashlight conditions (using the same Polaroid CU5 camera), for position and size of the redness areas around the ischial tuberosities. Pressure sore grading was by visual examination using the Shea (1975) classification. Maximum pressures were recorded by adjusting the aperture on the camera until the 'white' pressure contour has disappeared on the monitor and the aperture setting noted for both the regions around the left and right ischial tuberosities and, where appropriate, the sacrum. The device is calibrated so that a relationship, although nonlinear, between pressure level and colour contour is known.

A parallel video signal is taken to a Black and White 26 inch monitor which displays the unprocessed picture full size. This monitor has a frame supporting a role of clear plastic film that can be pulled in front of the monitor surface used for plotting the position of high pressures and used for the production of individual wheelchair cushions with appropriate 'cut out' areas corresponding to the high pressures.

\section{Subject Data}

Seventy-five normal age and weight-matched subjects were examined on the Ischiobarograph. Sixty-eight were males and the age ranged from i6 to 62 years, average 31 years. The average weight of the normal subjects was $60 \mathrm{~kg}$.

Twenty spinal cord injury patients, eight tetraplegic, I 2 paraplegic, were examined for underseat pressure patterns, average age 35 years, average weight $6 \mathrm{I} \mathrm{kg}$. Two were female. Details of all the spinal cord injury patients are shown in Table $\mathrm{I}$, one patient had previously undergone plastic 
surgery to a right open ischial pressure sore (patient T.B.).

All the subjects were examined clothed and unclothed whilst sitting on the device. Because of the high seating pressures observed the spinal injury patients were limited to 5 minutes on the Ischiobarograph.

TABLE I

Details of all the patients examined in this study and the biomechanical parameters measured ( ${ }^{\star}$ sacrum pressure $90 \mathrm{KPa}$, ${ }^{\star \star}$ sacrum pressure $93 \mathrm{KPa}$, +surgical repair to right ischium).

\begin{tabular}{|c|c|c|c|c|c|c|}
\hline Case & Age & History & Sore & ding & $\begin{array}{c}\text { Max. pressure } \\
\mathrm{KPa}\end{array}$ & $\begin{array}{l}\text { Ratio } L / R \\
\text { max. pressure }\end{array}$ \\
\hline S.T. & $3 I$ & \multirow{2}{*}{$\begin{array}{l}\text { Trauma } \\
\text { C5/6 level complete } \\
\text { tetraplegic }\end{array}$} & $\mathbf{L}$ & $\mathbf{R}$ & & \\
\hline \multirow{3}{*}{$\begin{array}{l}\text { J.W. } \\
\text { J.S. }\end{array}$} & 37 & & - & I & I 2 I & 0.47 \\
\hline & 23 & $\begin{array}{l}\text { C5 level paraplegic } \\
\text { Trauma }\end{array}$ & 2 & 2 & I 87 & I.08 \\
\hline & \multirow{2}{*}{24} & $\begin{array}{l}\text { T6 paraplegic } \\
\text { Trauma }\end{array}$ & 4 & 2 & 217 & I.04 \\
\hline K.A. & & $\begin{array}{l}\text { C5 paraplegic } \\
\text { Trauma }\end{array}$ & 2 & 3 & 230 & 0.89 \\
\hline $\begin{array}{l}\text { L.B. } \\
\text { M.M. }\end{array}$ & 26 & $\begin{array}{l}\text { TI2 flaccid paraplegic } \\
\text { Gunshot wound }\end{array}$ & 2 & 4 & 235 & 0.83 \\
\hline L.C. & 52 & $\begin{array}{l}\text { Tro paraplegic } \\
\text { Trauma } \\
\text { Tr T }\end{array}$ & I & - & $107^{\star}$ & $3 \cdot 8 \mathrm{I}$ \\
\hline \multirow{2}{*}{$\begin{array}{l}\text { J.N. } \\
\text { G.M. }\end{array}$} & 68 & Trauma & & & 241 & \\
\hline & 24 & $\begin{array}{l}\text { C5/6 paraplegic } \\
\text { Trauma }\end{array}$ & - & $\mathbf{I}$ & 102 & $I \cdot 00$ \\
\hline \multirow{2}{*}{$\begin{array}{l}\text { W.L. } \\
\text { M.N. }\end{array}$} & 20 & $\begin{array}{l}\text { 15/6 paraplegic } \\
\text { Trauma }\end{array}$ & I & 2 & 223 & 0.92 \\
\hline & 59 & $\begin{array}{l}\text { C5/6 tetraplegic } \\
\text { Trauma }\end{array}$ & I & - & I 13 & $\mathrm{I} \cdot \mathrm{I} 8$ \\
\hline \multirow{2}{*}{$\begin{array}{l}\text { N.W. } \\
\text { G.F. }\end{array}$} & I9 & $\begin{array}{l}\text { T5 paraplegic } \\
\text { Trauma }\end{array}$ & I & 3 & 248 & 0.43 \\
\hline & 20 & $\begin{array}{l}\text { C7 tetraplegic } \\
\text { Trauma }\end{array}$ & 3 & 2 & 138 & $I \cdot I O$ \\
\hline \multirow[t]{2}{*}{ A.L. } & \multirow[t]{2}{*}{ I6 } & $\begin{array}{l}\text { C5 tetraplegic } \\
\text { Stab wound }\end{array}$ & I & - & I 17 & $\mathrm{I} \cdot 02$ \\
\hline & & T6 level paraplegic & - & - & 138 & $\mathrm{I} \cdot 20$ \\
\hline D.A. & $3 \mathrm{I}$ & $\begin{array}{l}\text { Trauma } \\
\mathrm{C} 4 / 5 \text { tetraplegic }\end{array}$ & - & 2 & I 2 I & $I \cdot I O$ \\
\hline G.R. & 27 & $\begin{array}{l}\text { Linal angioma } \\
\text { L2 paraplegic } \\
\text { Trauma }\end{array}$ & $\mathbf{I}$ & 2 & $38^{\star \star}$ & $\mathrm{I} \cdot 2 \mathrm{I}$ \\
\hline $\begin{array}{l}\text { T.F. } \\
\text { T.C. }\end{array}$ & 33 & $\begin{array}{l}\text { T4 paraplegic } \\
\text { Trauma }\end{array}$ & I & 2 & 204 & 0.91 \\
\hline D.R. & $3 \mathrm{I}$ & $\begin{array}{l}\text { C5/6 tetraplegic } \\
\text { Trauma }\end{array}$ & 3 & 3 & 177 & 0.93 \\
\hline \multirow{2}{*}{ T.B. } & \multirow{2}{*}{68} & T5 paraplegic & I & 4 & 202 & 0.47 \\
\hline & & L2/3 paraplegic & I & 4 & 210 & $\mathrm{I} \cdot 78^{+}$ \\
\hline Avera & 35 & 8 tetra/1 2 paraplegic & $1 \cdot 7$ & $2 \cdot 4$ & I 68 & $I \cdot 07$ \\
\hline
\end{tabular}




\section{Individual Case Reports}

Case I (L.B.) was a 65-year-old male weighing 6I $\mathrm{kg}$ with a complete flaccid traumatic paraplegic at the twelfth thoracic vertebra level. He displayed a chronic right open ischial pressure sore of Grade 4 on the Shea (1975) classification and a smaller ischial sore of Grade 2 on the left side. The pressure patterns are shown in Fig. 2 just prior to reconstructive

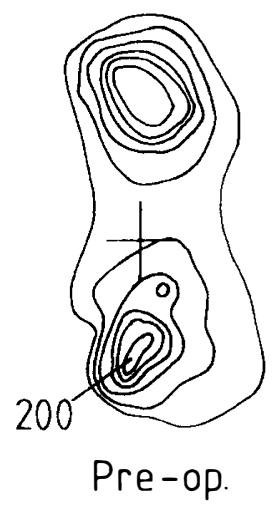

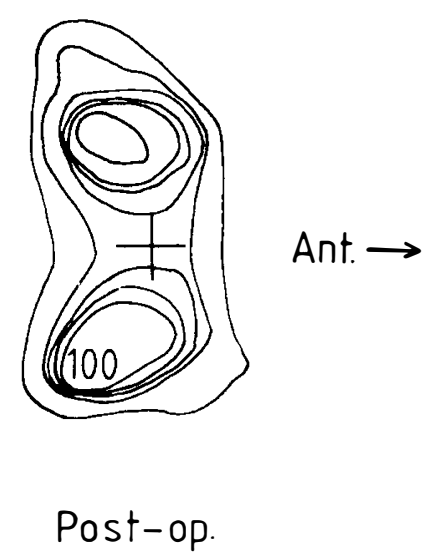

FIG. 2

Pressure patterns from case I (L.B.) before surgery on his right ischial tuberosity and after surgery (units of pressure in $\mathrm{KPa}$ ).

surgery to the right ischial region; maximum detected pressures were as high as $235 \mathrm{KPa}$ under the right ischial tuberosity. Following reconstructive surgery, which involved trimming of the ischial tuberosity and repositioning of a rotation flap of skin, the resulting pressure pattern 4 weeks after surgery is shown in Fig. 2. The maximum pressure under the right ischial tuberosity had been reduced to i I $5 \mathrm{KPa}$, but the pressure gradient posterolaterally was still high and may subject the tissue in this region to undesirable mechanical conditions.
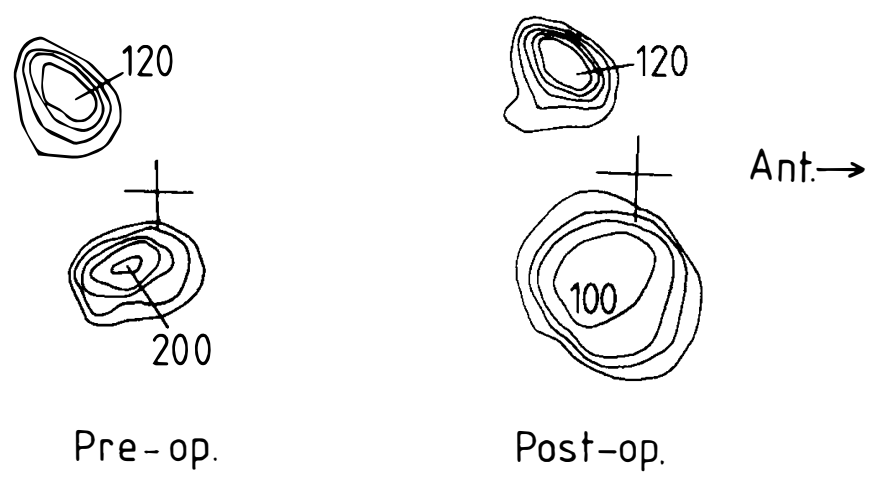

FIG. 3

Pressure patterns from case 2 (D.R.) before surgery and after implantation of a carbon fibre pad over the right ischial tuberosity (units of pressure in $\mathrm{KPa}$ ). 

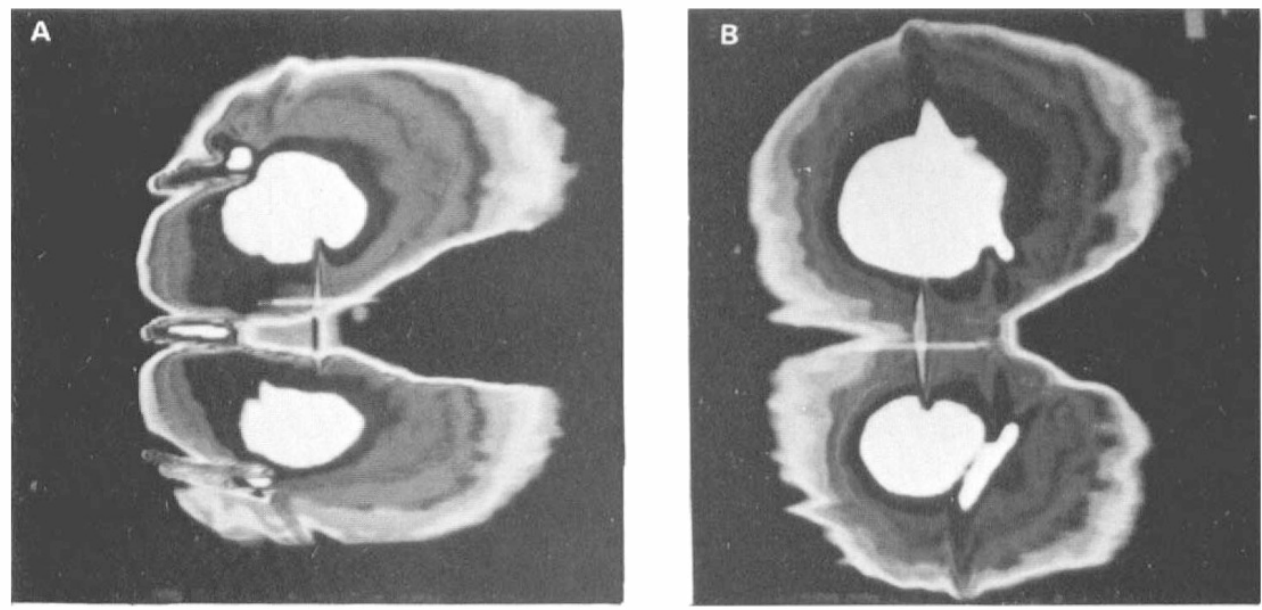

FIG. 4

(A) Pressure patterns under the buttocks of a normal subject of $60 \mathrm{~kg}$ weight clothed. The white areas are pressures in excess of $25 \mathrm{KPa}$. The cross indicates centre of force on the detecting surface. (B) Underseat pressure patterns of a normal subject $82 \mathrm{~kg}$ weight clothed. (The different tones on this monochrome view correspond with different colours seen on the original colour photograph.)

Case 2 (D.R.) is a 3 I-year-old male weighing $7 \mathrm{I} \mathrm{kg} \mathrm{(Fig.} \mathrm{3),} \mathrm{having}$ a complete traumatic paraplegic at the fifth thoracic level. He had an open pressure sore (Grade 4) under the right ischial tuberosity following a fall causing also a fracture of the bone around the tuberosity. The pressure sore was excised, the ischium partially covered and the wound directly closed. Four weeks later, when skin healing was well advanced and no infection was judged to be present, a carbon-fibre pad was inserted between the ischial remnant and the deep fascia. The maximum pressure under the right ischial tuberosity prior to the first operation was $202 \mathrm{KPa}$ which reduced to I05 $\mathrm{KPa}$ following implantation of the carbon fibre pad.

\section{Results}

In both the normal subjects and the spinal injury patients examined on the device there was a large variation in the pressure contour shapes which were not related to age, weight, gross anatomy or sex (Fig. 4). The pressures detected by the device under the ischial tuberosities were extremely high but bearing in mind that the detecting surface is flat and unyielding this is to be expected. Single layer clothing made little difference to the values of peak pressure area and shape in both groups of subjects.

Maximum pressures under the normal subjects on average were 65.2 $\mathrm{KPa}(489 \mathrm{mmHg})$ with a standard deviation about this mean of $28 \cdot 0 \mathrm{KPa}$ (2 $10 \mathrm{mmHg}$ ). Maximum pressures seen under the spinal injury patients had a much larger variation, the average value being I $68 \mathrm{KPa}$ (I283 $\mathrm{mmHg}$ ) with a much wider range of values. Strangely, the peak pressures under the ischial tuberosities were on average higher on the left by seven per cent (Table I). A weak correlation was seen between sore grading ratio and peak ischial pressure ration, the side with the higher sore classification having the higher ischial tuberosity pressure $(\mathrm{p}<\cdot \mathrm{OI})$. 
Underseat pressure patterns of the spinal injury patients showed marked differences from normal in area (which were very much reduced), shape (in symmetry and pattern), and peak pressure (which were much larger).

There was a correlation between areas of high pressure gradient (i.e. closely grouped colour contours) and the site of common occurrence of pressure sores seen in the spinal injury patient.

The centre of force was always between the ischial tuberosities and anterior to them. With the thighs only slightly raised above the detecting surface no contact pressures were observed under the thigh areas. When the legs were allowed to hang freely, the centre of force moved forward by on average $3 \mathrm{cms}$ in the normal subjects and $2.6 \mathrm{cms}$ in the spinal injury patients.

\section{Discussion}

The device described has its limitations, in particular the fact that the detecting surface is flat and rigid. However, it does present a display of the underseat pressures arising from large areas up to $50 \mathrm{~cm}$ square. It does not have the ability to measure shear forces at the interface which may be a contributory factor in pressure-sore development and blood flow occlusion, just as is applied surface pressure (Kosiak, I959). Tissue in areas of high pressure gradient may well be subjected to high shear stress, both being contributory to tissue breakdown. Location of high pressure gradients would appear to be useful in predicting the site at risk of possible tissue breakdown and nursing management of the patient can be adjusted accordingly. Topical medication can be employed if necessary and correctly designed supportive orthoses such as individually designed wheelchair cushions can be made with some precision. Description of a similar device has been recently published (Mayo-Smith and Cochran, I98I), using a modified wheelchair to locate high pressure regions prior to cushion modification. The modification of support surfaces and adjustable wheelchairs has been used in a clinical programme on wheelchair-bound spinal injury patients and the number of admissions for treatment of ischial pressure sores in the Glasgow region was dramatically reduced after its implementation (Ferguson-Pell et al., I980). The Ischiobarograph has been used in the design of pressure-distributing devices such as cushions for wheelchairs for spinal injury patients. We have used small interface (skin/cushion) pressure transducers to measure the effectiveness of the cushions made using the Ischiobarograph. There may be an advantage in employing a multiple transducer pressure pad system in this respect (Garber et al., I978).

One of the aims of surgical closure of pressure sores is to increase the area of pressure transfer and decrease the peak pressures likely to occur. The Ischiobarograph has proved to be useful in monitoring the effects of surgery on the re-distribution of pressure and consequently improvements in surgical techniques may arise from a study of area and pressure changes following reconstructive surgery around the ischial tuberosity.

The Ischiobarograph may possibly be used as a therapeutic tool. The patient could be shown the display of underseat pressure on the monitor whilst seated on the surface. The patient could relate to how localised and high the underseat pressures are with small changes in posture and position. These changes are seen virtually instantaneously. 
Despite its limitations we believe that this apparatus is of considerable value in the management of established pressure sores, in the assessment and fabrication of individually made pressure-distributing aids (e.g. wheelchair cushions), and as an aid to a programme of prophylactic measures designed to minimise the risk of pressure sore development.

\section{RÉSUMÉ}

On a développé un appareil qui peut signaler au-dessous du siège la répartition des pressions quand quelqu'un y est assis. Nous avons trouvé que cet appareil est particulièrement utile: pour surveiller l'influence de la chirurgie de lésions de pression sur la repartition des pressions vue de sous le siège; dans le dessin des coussins qui réduisent la pression; pour permettre au personnel qui traite les lésions de'épine de repérer les zones de haute pression où peut se produire l'écroulement de tissu (blessure de pression).

\section{ZUSAMMENFASSUNG}

Ein Gerät wurde entwickelt, das Druckverteilung am Gesäss während des Sitzens anzeigen kann. Wir stellten fest, dass dieses Gerät besonders dazu geeignet ist, nach chirurgischen Eingriffen zur Decubitusbehandlung die Druckfelder beim Sitzen zu überwachen, sowie bei der Konstruktion von druckmindernden Kissen zu helfen. Ausserdem ermöglicht dieses Gerät dem Personal der Abteilung für Wirbelsäulenverletzungen, Gebiete mit hohem Druck zu lokalisieren, wo Gewebszerfall (Dekubitus) in Erscheinung treten könnte.

\section{REFERENCES}

Betts, R. P. (1979). A simple grey-scale to colour converter. F. Med. Engng. Technol., 3, 3 I- -37 .

Bush, C. A. (1969). Study of Pressures on Skin under ischial tuberosities and thighs during sitting. Arch. Phys. Med. and Rehab., 50, 207-213.

Chodera, J. \& LORD, M. (1978). The Technology of the Pedobarograph. In: Biomechanical Research and Development Unit, Annual report, Roehampton, London, D.H.S.S, pp. I 59-I 79.

Drummond, D. S., Narechania, R. G., Rosenthal, A. N., Breed, A. L., Lange, T. A. \& DRUMMOND, D. K. (1982). A study of pressure distributions measured during balanced and unbalanced sitting. F. Bone ft. Surg., 64A, I034-1039.

Ferguson-Pell, M. W., Wilkie, I. C., Reswick, J. B. \& Barbenel, J. C. (i980). Pressure sore prevention for the wheelchair-bound spinal injury patient. Paraplegia, 18, 42-5I.

Ferguson-Pell, M. W. (I980). Design criteria for the measurement of pressure at body/ support interfaces. Eng. Medicine, 9, 209-2I4.

GARBER, S. L., KROUSKOP, T. A. \& CARTER, R. E. (I978). A system for clinically evaluating wheelchair pressure-relief cusions. Am. F. Occ. Ther., 32, 565-570.

Kosiak, M. (1959). Etiology and pathology of ischaemic ulcers. Arch. Phys. Med. and Rehab., 40, 62-69.

Lindan, O., Greenway, R. M. \& Piazza, J. M. (1965). Pressure distribution on the surface of the human body: I. Evaluation in lying and sitting positions using a 'Bed of Springs and Nails'. Arch. Phys. Med. E Rehab., 46, 378-385.

Mayo-Smith, W. \& Cochran, G. V. B. (I98I). Wheelchair cushion modification: Device for locating high-pressure regions. Arch. Phys. Med. E Rehab., 62, I35-136.

Minns, R. J. \& Sutton, R. A. (I982). Pressures under the ischium detected by a Pedobarograph. Eng. Medicine, II, I I I-I I 5.

SheA, J. D. (1975). Pressure Sores. Classification and Management. Clin. Orthop., I12, 89-100. 